\title{
CARTEL LENIENCY AND EFFECTIVE COMPENSATION \\ IN EUROPE: \\ THE AFTERMATH OF PFLEIDERER
}

\author{
Bruce Wardhaugh \\ Lecturer, \\ School of Law, \\ Queen's University Belfast \\ Belfast, BT7 1NN \\ United Kingdom \\ b.wardhaugh@qub.ac.uk
}

\author{
Forthcoming: \\ Web Journal of Current Legal Issues \\ Volume 19(3) September 2013 \\ Please cite to the Published Version: \\ http://webjcli.org//index
}

\begin{abstract}
The recent judgment in Pfleiderer exposes a tension between two goals of European cartel control policy: the ex ante desire to prevent and deter the formation of cartels, and the ex post desire to ensure an effective means by which victims of such conduct can have their harms redressed. The former goal is advanced by way of the administrative enforcement enhanced by a leniency programme, the latter by actions for damages at a decentralised, member state level. Leniency programmes are used to facilitate the acquisition of information by public agencies, but they have the effect of potentially providing information to private parties which can enhance cartel members' exposure to damages.

This paper considers Pfleiderer and other European and national court decisions which follow it, along with the recent Proposed Directive which aims to not just the enhance relationship between public and private enforcement, but also to improve the efficacy of private damages schemes in Europe.

I argue that although the judgement in Pfleiderer has significantly hindered European leniency schemes, the initiatives made in the Proposed Directive are steps forward. However, additional changes to harmonise public and private enforcement may be additional steps too far at this point in time.
\end{abstract}




\title{
CARTEL LENIENCY AND EFFECTIVE COMPENSATION \\ IN EUROPE: \\ THE AFTERMATH OF PFLEIDERER
}

\author{
Bruce Wardhaugh*
}

It is trite to note that effective anti-cartel regimes contain three elements: public and private enforcement procedures, and leniency programmes. Public regimes deter, private regimes compensate, and leniency programmes elicit information to enhance the effectiveness of public deterrence. An effective anti-cartel scheme will appropriately balance these components, ensuring that one will not hinder the efficacy of another. The recent judgments in Pfleiderer, ${ }^{1}$ CDC Hydrogene Peroxide ${ }^{2}$ Gas Insulated Switchgear (GIS) ${ }^{3}$ and Donau Chemie ${ }^{4}$ and the interpretation of Pfleiderer by the Amtsgericht Bonn ${ }^{5}$ and the English High Court ${ }^{6}$ expose a tension between two goals of European cartel control policy: the ex ante desire to prevent and deter the formation of cartels, and the ex post goal to ensure an effective means by which victims of such conduct can have their harms redressed.

This tension has been recognised by the European Legislators, who in June 2013 published a draft proposal for a Directive ${ }^{7}$ to govern private competition actions. The goal of

\footnotetext{
*Lecturer, School of Law, Queen's University Belfast (e-mail b.wardhaugh@ qub.ac.uk) An earlier version of this paper was delivered at the European Union and Competition Law Section of the Annual Meeting of the Society of Legal Scholars at the University of Bristol in September 2012. The author would like to thank those who commented there, and two anonymous reviewers for their suggestions. The usual caveats and disclaimers apply.
}

${ }^{1}$ C-360/09, Pfliederer v Bundeskartellamt, NYR (Opinion of A-G Mazák, 16 December 2010; Judgement, 14 June 2011)

${ }^{2}$ T-437/08, CDC Hydrogene Peroxide v Commission, NYR (15 December 2011)

${ }^{3}$ T-344/08, En BW Energie Baden-Württemberg AG v Commission, NYR (22 May 2012), hereafter " $E n B W$ "

${ }^{4}$ C-536/11, Bundeswettbewerbsbehörde v Donau Chemie and Others, NYR (Opinion of Advocate General Jääskinen, 7 February 2013; Judgement, 6 June 2013)

${ }^{5}$ Pfliederer v Bundeskartellamt 51 Gs 53/09 AG Bonn (18 January 2012)

${ }^{6}$ National Grid Electricity Transmission PLC v ABB Ltd et al [2012] EWHC 869 (Ch) (4 April 2012), hereafter "NGET"

${ }^{7}$ Proposal for a Directive of the European Parliament and of the Council on certain rules governing actions for damages under national law for infringements of the competition law 
this Directive is to regulate and harmonise the interaction of public and private enforcement of competition law within Europe, particularly with regard to disclosure of leniency materials, quantification of damages and availability of defences. In this paper, I explore the tension created by the interaction of public and private enforcement and associated leniency programmes in the European regime with the view of assessing the efficacy of the proposed Directive. My thesis is that while the judgement in Pfleiderer, by refusing to recognise or establish a hierarchy between public and private enforcement goals, has opened difficulties with disclosure of leniency materials, the Proposed Directive goes part of the way to resolve these difficulties. However a more complete resolution of these difficulties would necessitate a legislative programme that would contain elements which may be steps too far at this time.

This paper is structured as follows. At the outset, I will present a model of a cartel control system, indicating its features and their interactions. The model will be illuminated by comparisons with the US system, which through evolution has developed into a very sophisticated regime, and is used as a paradigm for other jurisdictions to adopt. ${ }^{8}$ I next turn to concerns found in the private enforcement of competition law (particularly regarding the redress of damages), identifying those concerns which are exacerbated by leniency programmes. I then turn to the recent court activity at the EU and Member State level to show the tensions found in the European regime. In the final section of the paper I assess the European legislators' efforts at making the EU's regime more workable.

\section{Features of a Cartel Control System}

The objective of a public cartel control system is to provide an ex ante deterrent against economic collusion. An ideal public programme sets the expected costs of participating in a cartel to be greater than the benefits; consequently a rational actor will avoid such activity. ${ }^{9}$ In one model, public enforcement consists mainly of pecuniary sanctions directed at firms or undertakings who engage in such activity. In the other model, sanctions against firms are supplemented with criminal sanctions against individuals who

provisions of the Member States and of the European Union (11 June 2013) COM(2013) 404 final (hereafter "Proposed Directive")

${ }^{8}$ Indeed, we note that the leniency regimes of the EU (including the model ECN programme) and Canada have been inspired by the American model.

${ }^{9}$ Gary S. Becker's work provides the formal background for this arraignment of incentives, see, "Crime and Punishment: An Economic Approach" (1968) 76 Journal of Political Economy 169. 
engage in price-fixing and related activity. By directing sanctions at individuals, such criminal provisions radically alter the incentives of those contemplating engaging in cartel activity.

A private enforcement procedure, on the other hand, serves to compensate ex post those who have been harmed by that activity; by permitting those harmed a means of compensation for their losses. Private enforcement, in the context of the $E U$, acts not merely to vindicate an affected individual's right to damages for infringement of competition law ${ }^{10}$ but also to provide some supplementary deterrence to the public enforcement regime. Such a supplement is effective in situations where, for instance, work-load prioritisation concerns preclude the public authority's investigation and prosecution of an alleged infringement; or those cases where the evidence obtained during an investigation is insufficient to prove the infringement at a criminal standard, but will nonetheless support its proof at a lesser, civil, standard.

Private enforcement in the American context, acts as an alternative deterrent: some 90 per cent of antitrust matters are privately litigated. ${ }^{11}$ A significant reason for this deterrent effect lies in the availability of treble damages. From a Beckerian perspective, ${ }^{12}$ an act is deterred only if the expected costs of engaging in the act are outweighed by its expected benefits. Where the probability of detection of the act is less than 1 (as it will be in any "real world" public or private enforcement regime), the sanction imposed must be greater than the offender's gain (e.g. as measured by damages). This logic applies whether the enforcement regime (and the standard of proof) is civil or criminal. The treble damages element provided for by the Sherman Act gives the necessary uplift required to alter the American system from a compensatory regime to an effective deterrent.

Further, it may be possible to adjust incentives in private litigation to encourage the detection of cartel activity, thereby uncovering infringements which may not have come to

\footnotetext{
${ }^{10}$ C-453/99 Courage Ltd $v$ Bernard Crehan and Bernard Crehan $v$ Courage Ltd and Others [2001] ECR I-6297 and Cases C-295/04 to C-298/04, Vincenzo Manfredi and Others v Lloyd Adriatico Assicurazioni SpA and Others [2006] ECR I-6641

${ }^{11}$ See e.g. Ilya R. Segal and Michael D. Whinston "Public vs. Private Enforcement of Antitrust Law: A Survey" Stanford Law and Economics Olin Working Paper No. 335. Available at: < http://papers.ssrn.com/sol3/papers.cfm?abstract id=952067> accessed 30 August 2013.

${ }^{12}$ See Becker (n 9)
} 
the authorities' attention. ${ }^{13}$ One can view the fees earned by successful plaintiff's counsel in class action anti-trust litigation as a means of rewarding the private investigation and prosecution of such activity. As a point of illustration, it is useful to note that among the original intentions in the minds of the framers of the US Sherman and Clayton Acts was to make the availability of private remedies more generally accessible, so as to serve as an incentive for "Private Attorneys General," to supplement the enforcement efforts of public authorities. $^{14}$

Leniency (and whistle-blowing ${ }^{15}$ ) programmes are designed to engineer the acquisition of information about cartel activity. ${ }^{16}$ Typically such programmes grant full amnesty to the first to inform (subject to varying conditions), with reductions in sanctions potentially available to others who provide information, should the information be of sufficient value and/or other conditions are met. ${ }^{17}$

${ }^{13}$ This may be as result of the specialised knowledge which is possessed by participants in an industry, but of which the antitrust authority may be ignorant.

${ }^{14}$ See the United States Antitrust Modernisation Commission, Report and Recommendations (Washington, 2007) p. 243: "Private antitrust enforcement plays a critically important role in implementing the U.S. antitrust laws. From the outset, Congress contemplated that private parties would play a central role in enforcement of the Sherman Act. Indeed, Senator Sherman believed that individuals should act as 'private attorneys general,' and that the antitrust laws should encourage such enforcement."

${ }^{15}$ The literature typically refers to leniency programmes as being targeted to firms (undertaking) who self-report to avoid all (or some) of a potential fine, and whistle-blowing programmes as being targeted to individuals who avoid criminal sanctions in exchange for information on price-fixing activity. Strictly speaking, one can distinguish among individual and corporate immunity programmes (complete immunity from civil and/or criminal consequences) in exchange for information and individual and corporate leniency programmes (reduction in sanctions in exchange for information and/or cooperation during an investigation).

${ }^{16}$ See e.g. Cécile Aubert, Patrick Rey and William E. Kovacic, "The Impact of Leniency and Whistle-Blowing Programs on Cartels" (2006) 24 International Journal of Industrial Organization 1241 at $1242-43$.

${ }^{17}$ As EU competition law only penalises undertakings, its leniency programme is thus limited to these entities. For details see Commission Notice on Immunity from fines and reduction of fines in cartel cases [2006] OJ C-298/17. The US leniency policy for individuals is described by the Antitrust Division of the Department of Justice, "Leniency Policy for Individuals" available at < http://www.justice.gov/atr/public/guidelines/0092.htm> accessed 30 August 2013; and for details of the UK's leniency programme, see Office of Fair Trading Leniency and No-Action OFT's Guidance Note in the Handling of Applications (London: OFT, 2008). 
The effectiveness of such programmes in uncovering cartel activity is widely touted. Discussing the US experience, Scott Hammond noted:

The Antitrust Division has spent the last two decades building and implementing a "carrot and stick" enforcement strategy by coupling rewards for voluntary disclosure and timely cooperation pursuant to the Antitrust Division's Corporate Leniency Program with severe sanctions. In addition, the Antitrust Division utilizes all available investigatory tools to create a significant risk and fear of detection and prosecution for violators of U.S. antitrust laws. The seeds of this "carrot and stick" enforcement strategy were planted by the Antitrust Division in the mid1990s and began to bear fruit over the next decade. ...

The single most significant development in cartel enforcement is the proliferation of effective leniency programs. The advent of leniency programs has completely transformed the way competition authorities around the world detect, investigate, and deter cartels. Cartels by their nature are secretive and, therefore, hard to detect. Leniency programs provide enforcers with an investigative tool to uncover cartels that may have otherwise gone undetected and continued to harm consumers. While the notion of letting hard core cartel participants escape punishment was initially unsettling to many prosecutors, the Antitrust Division recognized that the grant of full immunity was necessary to induce cartel participants to turn on each other and self-report, resulting in the discovery and termination of the conduct, the successful prosecution of the remaining cartel participants, and damage recovery for victims. Moreover, the hope was that the benefits of leniency would extend beyond the cartels it directly uncovered and that the very existence of the leniency policy would be viewed by executives as raising the risk of detection and punishment, leading to greater deterrence of cartel activity. ${ }^{18}$

\footnotetext{
${ }^{18}$ Scott D. Hammond (Deputy Assistant Attorney General for Criminal Enforcement, Antitrust Division, U.S. Department of Justice) "The Evolution of Criminal Antitrust Enforcement Over the Last Two Decades" Speech Presented to The 24th Annual National Institute on White Collar Crime (Miami, 25 February 2010) available at: < http://www.justice.gov/atr/public/speeches/255515.htm > accessed 30 August 2013
} 
Such views are mirrored in Europe by the present EU Competition Commissioner, Joaquín Almunia:

When do companies decide to take advantage of our leniency programme and decide to cooperate with us?

Many take this decision as a response to external events; for instance, when investigations in one sector make the company look into its other lines of business.

Other immunity applications are triggered by internal events; for instance, when a company has a new CEO or is acquired by another company and the cartel is uncovered in the due diligence exercise; or when an employee blows the whistle.

Immunity and reductions help companies comply with our rules because they raise the risk of being exposed by the other members of the cartel.

And we know that - apart from the level of sanctions - deterrence depends on the likelihood that the illegal behaviour is discovered and punished.

Although the cooperation of companies is very important, we also investigate cartel cases ex officio; as a matter of fact, a quarter of our decisions are initiated without a request for immunity.

In these cases too, we motivate companies with lower fines if they decide to cooperate with the investigation - and many of them do. ${ }^{19}$

Leniency programmes work by attempting to induce distrust among members of a cartel, and thereby further destabilise an already unstable organisation. By reducing or eliminating penalties for participants who provide evidence of the existence and workings of the cartel, a

\footnotetext{
${ }^{19}$ Joaquín Almunia "Compliance and Competition Policy," Speech Presented to Businesseurope and US Chamber of Commerce Competition Conference (Brussels 25 October 2010) available at: $<$ http://europa.eu/rapid/pressReleasesAction.do?reference=SPEECH/10/586\&format=HTML \&aged $=0 \&$ language $=E N \&$ guiLanguage $=$ en $>$ accessed 30 August 2013
} 
leniency programme can make defection from the cartel a cost effective and hence rational business decision. Hence, in addition to distrust among cartel members regarding other members' willingness to stick to the terms of the cartel agreement (e.g. fixed prices, quotes, etc.), additional distrust is sewn regarding whether another member will turn everyone else in. $^{20}$

Yet, in spite of a carrot being held out, a potential leniency applicant may not head toward it. There may well be a fear of a second stick which the carrot hides. This stick is not one held by the competition authorities. It is the stick of private damages. The incentive to provide information to avoid (or mitigate) antitrust penalties can be offset by the desire not to have the information provided used against it in subsequent civil claims. The fear of course, rests in a firm's desire not to hand over on a proverbial silver platter vital information to the Plaintiffs' Bar which can then be used against it in subsequent civil actions.

In the US, where the Sherman Act provides for triple damages, ${ }^{21}$ this fear served to blunt the effects of the leniency programme as it was originally formulated. To realign incentives, the Antitrust Criminal Penalty Enhancement and Reform Act of 2004 (ACPERA) ${ }^{22}$ de-trebles damages and decouples joint and several liability for recipients of immunity. ${ }^{23}$ Although a condition of leniency in the US is making payment of restitution to those harmed by the applicant's conduct ${ }^{24}$ the successful applicant is better off: they avoid criminal penalties (not only for the firm's activities, individual members of the firm also benefit from immunity), they pay only single damages, and they are not responsible for the harm their fellow cartelists occasioned if damages cannot be recovered from the others.

Further, I note the Sherman Act provides for sanctions that are also directed towards individuals. These are used, and people frequently go to jail for cartel activity. ${ }^{25}$ Individual

\footnotetext{
${ }^{20}$ The game theorist views leniency programmes as enhancing the Prisoners' Dilemma structure of such organisations: see e.g. Massimo Motta, Competition Policy: Theory and Practice (Cambridge: Cambridge University Press, 2004) pp 544 - 45 for an overview. ${ }^{21} 15$ U.S.C. $\S \S 1$ and 3

${ }^{22}$ Pub. L. No. 108-237, § 213, 118 Stat. 666, 667 (2004)

${ }^{23}$ ACPERA $\S 213$

${ }^{24}$ Department of Justice, Antitrust Division, “Corporate Leniency Policy” (10 August 1993), available at: http://www.justice.gov/atr/public/guidelines/0091.htm (accessed 30 August 2013).

${ }^{25}$ Between 1999 and 2009, 175 individuals were sentenced for antitrust offences of which 83 were sentenced to prison with a median sentence of six months. The range was two weeks to four years. The Department of Justice's statistics indicate that during 2000-2009 the average prison sentence for price-fixing was 19 months, in the years 2010 and 2011 the average rose
} 
sanctions and leniency have a further destabilising effect beyond sanctions and leniency directed towards undertakings. Corporations act through an agency model: corporations do not engage in cartel activity, people do on behalf of the corporations. Likewise, corporate agents may have different motivations than the best interests of other constituents of a corporation. Motta expresses this in the following terms:

Shareholders care about profits, but managers care about their individual utility, determined by wage, career prospects, as well as the level of effort and time they have to put into the job. The manager might also care about profits (typically, the shareholders will write a contract where his remuneration increases with the firm's profits), but in general he will care about other things, too. As a result, when he takes decisions about technologies (or he has to take actions, which affect the firm's costs) he might not have the right incentives to adopt the most efficient ones (that is, those which maximize profits). ${ }^{26}$

Cartel activity typically begins with the agent's desire to pursue their own interests. ${ }^{27}$ The firm may benefit, but a significant amount of the benefits from cartel activity accrue to the agent. When it comes to evaluate participation on the cartel, the agents may not take into account the full costs of participation or defection into account, discounting those costs which

to 24 months. See Beryl A. Howell, "Sentencing of Antitrust Offenders: What Does the Data Show?" (U.S. Sentencing Commission, 2010) available at: http://www.ussc.gov/About_the_Commission/About_the_Commissioners/Selected_Articles/ Howell_Review_of_Antitrust_Sentencing_Data.pdf and Department of Justice, Antitrust Division, "Division Update Spring 2012” available at: http://www.justice.gov/atr/public/division-update/2012/criminal-program.html (both sites accessed 30 August 2013).

${ }^{26}$ Motta, Competition Policy (n 20) p 47

${ }^{27}$ Few cartels have their genesis in the boardroom. The largest exception was the fine art Christie's-Sotheby's) cartel, where the conspirators included the chief executive of Sotheby's and the Chairmen of both companies, see Orley Ashenfelter and Kathryn Graddy, "Anatomy of the Rise And Fall of a Pricefixing Conspiracy: Auctions at Sotheby's and Christie's" (2005) 1 Journal of Competition Law and Economics 3, 5 - 6. See also the illuminating table contained in Andreas Stephan, "See No Evil: Cartels and the Limits of Antitrust Compliance Programs" (2010) 31 Company Lawyer 231, which analyses 40 international cartels prosecuted in the US or in the EU between 1998 and 2008. It lists the cartel and the corporate positions of the individuals involved. Although the individuals were generally quite senior corporate employees, few were board members, or in similar senior positions. 
they do not have to personally bear. This is exacerbated to the extent that any costs can be off-loaded onto other corporate constituents.

However, by imposing individual liability for such activity, the American system readjusts the incentives. Agents, if convicted have to bear the costs of this activity. Prison sentences cannot be off-loaded, or indemnified, in the way that fines can be. Thus individual sanctions can further exploit the instability contained in cartel activity by not only pitting the interests of one firm against another, but also by pitting the interests of the agents against those of the firm.

\section{Private Enforcement}

The European courts have recognised the importance of private damages in contributing to the maintenance of the European competition regime. The well-known recognition of this is found in Courage and Crehan:

As regards the possibility of seeking compensation for loss caused by a contract or by conduct liable to restrict or distort competition, it should be remembered from the outset that, in accordance with settled case-law, the national courts whose task it is to apply the provisions of Community law in areas within their jurisdiction must ensure that those rules take full effect and must protect the rights which they confer on individuals .... .

The full effectiveness of Article 85 of the Treaty and, in particular, the practical effect of the prohibition laid down in Article 85(1) would be put at risk if it were not open to any individual to claim damages for loss caused to him by a contract or by conduct liable to restrict or distort competition.

Indeed, the existence of such a right strengthens the working of the Community competition rules and discourages agreements or practices, which are frequently covert, which are liable to restrict or distort competition. From that point of view, actions for damages before the national courts can make a significant contribution to the maintenance of effective competition in the Community. ${ }^{28}$

${ }^{28}$ Courage and Crehan (n 10) at paras $25-27$ 
However, to effectively redress harms done, Plaintiffs (or their counsel) must obtain information to accurately quantify the harm done by the cartel activity. The mere existence of cartel activity is insufficient to prove damages.

Proving damages in cartel claims is different from proof of damages in other financial matters. In a breach of contract claim, where - say a seller refused to deliver the goods as and when promised - one need only look at difference in the contract price and the market price to accurately quantify the damages. In cartel matters, this quantification is different, as it is the market price which is the very focus of the inquiry. Accordingly, one needs to engage in a hypothetical (and thus more difficult) inquiry to determine what the market price would have been but for the cartel activity. Likewise, issues of causation are germane, as mere participation in a cartel is insufficient on its own to establish the quantum of loss caused by participation.

The information which can be useful to construct the hypothetical market is in the hands of the cartel members and is not readily accessible from other sources. This information asymmetry is described by the Commission thus:

Even where claimants are in a position to describe and prove the factual elements necessary for finding an infringement, having to demonstrate in detail the causation and quantification of their damages remains a particular difficulty in competition cases. To establish their damage, claimants have to compare the anti-competitive situation to a situation which would have existed in the absence of the infringement, i.e. a hypothetical competitive market. In a breach of contract case, a claimant can normally use market prices at the time of the breach of contract as the benchmark for calculating his loss. However, in a typical competition case, the claimant cannot rely on the prices at the time of the infringement and has to establish what the price would have been in the absence of the restriction of competition. For this purpose, he will often depend on information that is in the sphere of the defendant and possibly their partners in the infringement: for example, notes on the price overcharges agreed secretly between cartel members, details on how and when they influenced price and other parameters of competition, or internal documents of the infringer showing his analysis of market conditions and developments. Also the reconstruction of a hypothetical competitive market to quantify the damage caused by the infringer usually presupposes knowledge of facts on the commercial activities of the infringer and other players on the relevant market. The same or similar types of difficulty arise 
in the context of causation, e.g. when claimants try to identify the precise elements of anti-competitive behaviour by an infringer that have caused the claimants damage, or the extent to which several infringers have individually contributed to the damage caused. $^{29}$

In addition to its utility to Plaintiffs' counsel, this information is absolutely essential to public authorities in their investigation of this activity, and is often contained in leniency applications or in clarifications of leniency application materials. Given the cloak of secrecy used by cartels, interpreting cryptic documents and other intentionally opaque communication among cartel members to establish what they mean is essential for determining the scope, duration and economic consequences of the infringement.

Accordingly the existence of this information identifies a number of needs within the cartel control system. There is the need of the authorities to receive this information to prosecute cartel activities, and the resulting need of leniency applicants to provide the information to benefit from the programmes. There is also the need of Plaintiffs' counsel to obtain this information to successfully prosecute their clients' private actions, and a corresponding need for leniency applicants not to have this information disclosed, so as not to increase their exposure to claims.

\section{Pfleiderer and the EU's Difficulty}

The crux of the difficulty is simply this: by applying for leniency, the applicant (though almost certainly obtaining a savings on any fine) opens itself to greater exposure for civil liability, should the content of the leniency application find its way into the hands of the Plaintiffs' Bar. The concerns are well expressed in the opinion of Advocate General Mazák in Pflederer, who noted:

In my view, in such circumstances the disclosure by a national competition authority of all the information and documents submitted to it by a leniency applicant could seriously undermine the attractiveness and thus the effectiveness of that authority's leniency programme as potential leniency applicants may perceive that they will find themselves

\footnotetext{
${ }^{29}$ White Paper on Damages Actions for Breach of the EC Antitrust Rules (2 April 2008) $\{\mathrm{COM}(2008) 165$ final $\}$ \{SEC (2008) 405\} \{SEC (2008) 406\} para 89. This paragraph is also quoted in NGET at para 40.
} 
in a less favourable position in actions for civil damages, due to the self-incriminating statements and evidence which they are required to present to the authority, than the other cartel members which do not apply for leniency. Thus while a potential leniency applicant may benefit from immunity from or a reduction in fines, that benefit may be perceived as being outweighed by an increased risk of liability for damages where access to the leniency file is granted, particularly in cases where cartel members are jointly and severally liable under national rules of civil procedure. A cartel member may therefore abstain from applying for leniency altogether or alternatively be less forthcoming with a competition authority during the leniency procedure. ${ }^{30}$

The possibility that leniency materials might be disclosed to Plaintiffs' counsel serves as a disincentive to apply for leniency, or if leniency is applied for, to be less than forthright with the authorities in providing information to them.

There are two obvious means of obtaining the information contained in a leniency application: obtaining the material from the competition authority which investigated the cartel (and subsequently granted leniency) or by obtaining in jurisdictions which permit discovery of opposing litigants, obtaining the information from the defendant as part of the discovery process. By discovering a Defendant in this way, a Plaintiff is likely to obtain the same information (if not copies of the same documents) which is found in the competition authority's files. The former means was considered by the ECJ in Pfliederer, the latter by the English High Court in NGET.

\section{a. Pfliederer: Disclosure of the Agency's File}

Pfleiderer involved a decorating paper cartel, of which Pfleiderer was a customer. During the cartel's duration, it had purchased over $€ 60$ million worth of goods from the undertakings involved. ${ }^{31}$ To prepare its action for damages, Pfleiderer sought access to the leniency file held by the Bundeskartellamt (BKA) which had earlier fined the cartel participants. ${ }^{32}$ The BKA granted partial access to the file, "sending three decisions imposing fines, from which identifying information had been removed, and a list of the evidence

\footnotetext{
${ }^{30}$ Pfleiderer (n 1) Opinion of the AG para 38

${ }^{31}$ Pfleiderer (n 1) Judgement para 10

${ }^{32}$ Ibid paras $11-12$
} 
recorded as having been obtained during the search." 33 Pfleider renewed its request, ${ }^{34}$ but ultimately made an application to the Amtsgericht Bonn for access to the entire file. The Amtsgericht provisionally granted access to the entire file, but stayed its decision pending a reference to the ECJ.

Although the Court was aware of the disincentives resulting from the disclosure of leniency applications, its reasoning for rejecting blanket non-disclosure for the leniency application (or even for specific elements of the leniency application), the Court's reasoning was somewhat perfunctory. The judgment recognised the recognised the role of leniency programmes in public enforcement, and noted that they "are useful tools if efforts to uncover and bring to an end infringements of competition rules are to be effective and serve, therefore, the objective of effective application of Articles 101 TFEU and 102 TFEU."35 As such the Court conceded:

... The effectiveness of those programmes could, however, be compromised if documents relating to a leniency procedure were disclosed to persons wishing to bring an action for damages, even if the national competition authorities were to grant to the applicant for leniency exemption, in whole or in part, from the fine which they could have imposed.

The view can reasonably be taken that a person involved in an infringement of competition law, faced with the possibility of such disclosure, would be deterred from taking the opportunity offered by such leniency programmes, particularly when, pursuant to Articles 11 and 12 of Regulation No 1/2003, the Commission and the national competition authorities might exchange information which that person has voluntarily provided. ${ }^{36}$

\footnotetext{
${ }^{33}$ Ibid para 11

${ }^{34}$ Ibid para 12: "Pfleiderer then sent a second letter to the Bundeskartellamt expressly requesting access to all the material in the file, including the documents relating to the leniency applications which had been voluntarily submitted by the applicants for leniency and the evidence seized. On 14 October 2008 the Bundeskartellamt partly rejected that application and restricted access to the file to a version from which confidential business information, internal documents and documents covered by point 22 of the Bundeskartellamt's notice on leniency had been removed, and again refused access to the evidence which had been seized."

${ }^{35}$ Ibid para 25

${ }^{36}$ Ibid paras $26-27$
} 
Notwithstanding the reasonableness of this view and the effect that such disclosure would have on effective public enforcement of competition law, the Court centred on considerations of redress of private wrongs and the contribution that such redress makes to European competition policy.

Recognising the importance of a private means to redress harms done by conduct which is contrary to Article 101 TFEU, a principle established in Courage and Crehan and Manfredi, the court noted that private enforcement in the form of "actions for damages before national courts can make a significant contribution to the maintenance of effective competition in the European Union... . ${ }^{37}$ The Court then reasoned:

Accordingly, in the consideration of an application for access to documents relating to a leniency programme submitted by a person who is seeking to obtain damages from another person who has taken advantage of such a leniency programme, it is necessary to ensure that the applicable national rules are not less favourable than those governing similar domestic claims and that they do not operate in such a way as to make it practically impossible or excessively difficult to obtain such compensation (see, to that effect, Courage and Crehan, paragraph 29) and to weigh the respective interests in favour of disclosure of the information and in favour of the protection of that information provided voluntarily by the applicant for leniency.

That weighing exercise can be conducted by the national courts and tribunals only on a case-by-case basis, according to national law, and taking into account all the relevant factors in the case. ${ }^{38}$

As a result, the Court concluded:

In the light of the foregoing, the answer to the question referred is that the provisions of European Union law on cartels, and in particular Regulation No 1/2003, must be interpreted as not precluding a person who has been adversely affected by an infringement of European Union competition law and is seeking to obtain damages

\footnotetext{
${ }^{37}$ Ibid para 29

${ }^{38}$ Ibid paras 30 - 31
} 
from being granted access to documents relating to a leniency procedure involving the perpetrator of that infringement. It is, however, for the courts and tribunals of the Member States, on the basis of their national law, to determine the conditions under which such access must be permitted or refused by weighing the interests protected by European Union law. ${ }^{39}$

In arriving at its conclusion, the Court made no apparent attempt to weigh public enforcement goals (ex ante deterrence) against the goals of private enforcement (i.e. an effective remedy and "a significant contribution to the maintenance of effective competition in the European Union"), and merely stated that disclosure was a matter for national courts under national law with the standard "no less favourable conditions" proviso.

While the Court's reasoning may have been perfunctory, it contained few surprises. In the absence of Regulations or harmonising Directives to the contrary, determination of damages is a matter for the Courts of Member States under national law (which also includes national civil procedure rules) and disclosure rules are part of such law. The only potential surprise was the requirement that national courts engage in the weighing exercise on a "caseby-case basis," thereby casting doubt on the ability of courts or national legislatures to exempt certain classes of documents from disclosure.

On 18 January 2012, the Amtsgericht Bonn ruled that under German National Law, Pfleiderer could not have access to the BKA's leniency file. That Court relied on a provision of the German Code of Criminal Procedure, ${ }^{40}$ which precluded access to the file if such access would endanger either the relevant investigation or any other investigation. In examining the purposes of the Commission's and the BKA's leniency programmes, the Court noted that the effectiveness of cartel investigation and leniency programmes could be hindered by such disclosure. ${ }^{41}$ Accordingly access to the file was denied.

\footnotetext{
${ }^{39}$ Ibid para 32

${ }^{40}$ Strafprozessordnung (StPO) $\$ 406 \mathrm{e}$

41 "Die Wirhsamkeit dieser Programme könnte jedoch durch die Übermittlung von Dokumenten eines Kronzeugeunverfahrens an Personen, die eine Schadensersatzklage erheben wollen, beeinträchtigt warden, auch wenn die Nationalwettbewerbsbehörden dem Kronzeugen die Geldbuße, die sie hätte verhängen können, ganz oder teilweise erlassen ... ." ("The effectiveness of these [leniency] programmes, could however be affected by the transfer of documents from a leniency applicant to persons who wish to bring an action for damages, even if National Competition Authorities reduce in whole or part the fine that they would otherwise impose ..." Present author's translation) (Bechluss 16 January 2012, para II.3.b.aa)
} 
b. NGET: Discovery of the Defendant

The English High Court, in NGET, was called upon to address accessing the same type of documents (the Defendant's submissions which would form part of the Comnpetition Authority's leniency file), in an application for discovery of the defendant. Mr Justice Roth rejected the claim that the Defendants had a legitimate expectation of confidentiality ${ }^{42}$ regarding the contents of their leniency application:

I do not consider that the principle of legitimate expectation has any bearing in the present case. Both the 2002 and the 2006 versions of the Leniency Notice make clear that the grant of immunity or leniency cannot protect an undertaking from the civil law consequences of its infringement of Article 101: 2002 Notice, para 31; 2006 Notice, para 39. The Notices cannot govern the application by a national court of its procedural rules in civil proceedings, as the ECJ expressly stated in Pfleiderer: para 21. Although Mazak AG in his Opinion in Pfleiderer expressed the view that the leniency applicants may have a legitimate expectation that leniency documents would not be disclosed, that view was not adopted by the ECJ. Nor did the Court make its ruling prospective, so that it would apply only to leniency applications made after the date of the judgment when the applicants would be aware of the potential for disclosure. $^{43}$

Rather, the relevant factor for English Courts to consider regarding the disclosure of leniency files is proportionality.

Mr Justice Roth reasoned:

The Commission also submits that a relevant factor is whether the disclosure sought is proportionate, having regard to the potentially adverse effect of disclosure on leniency programmes. I agree, and indeed proportionality is in any event a consideration in applying the English rules on disclosure and inspection: CPR rule 31.3(2) and PD 31A, para 2. Here, because of the balancing exercise proportionality assumes particular significance in a different context from reference to the size of the

\footnotetext{
${ }^{42} N G E T$ (n 6) para 32

${ }^{43}$ Ibid para 34
} 
claim and the amount of work involved. In my judgment, proportionality should be considered in terms of (a) whether the information is available from other sources, and (b) the relevance of the leniency materials to the issues in this case. ${ }^{44}$

In ordering disclosure, the Court noted that the cartel was sophisticated, operated with regular meetings and kept cryptic records, which would require assistance in interpretation. Since the Defendants were unlikely to provide NGET with statements interpreting these documents, there was no substitute for the information contained in the leniency application. ${ }^{45}$ As Roth $\mathrm{J}$ concluded, "Accordingly, in the circumstances of this case, to the extent that the information in the disclosure sought is of real assistance, I do not consider that other means are available, at least not without excessive difficulty, for NGET to derive that information." 46

Similarly, in $E n B W$ the General Court (GC) was called upon to determine the Commission's duty of disclosure of their file in the same cartel as was the concern in NGET. In many respects that Court's job was easier. In denying EnBW's request for disclosure pursuant to Article 2(1) of Regulation No 1049/2001, ${ }^{47}$ the Commission had categorised the documents it held into a number of categories, and then on a category-by-category basis refused access to the documents on the basis that certain exceptions provided by the Regulation applied to that category. As the Commission's Decision to refuse access was not done on a document-by-document basis, it was clearly erroneous in law, and thus annulled by

${ }^{44}$ Ibid para 39
${ }^{45}$ Ibid para 43 :

This was a very sophisticated international cartel operated with regular meetings. Of its nature, documents which reveal the cartel's activities are limited and their meaning is often opaque. It is presumably for those reasons that the Commission relied on information and extracts from the leniency statements in articulating its findings about the cartel in its Decision. Although the Commission suggested that NGET might be able to get instead appropriate evidence by way of witness statements from employees of the participants in the cartel that supplied the UK market, none of the defendants suggested that such individuals are likely to provide NGET with statements. And even statements from a few individuals are unlikely to be an adequate substitute for the comprehensive overview of the cartel obtained by the Commission from the participating undertakings.

${ }^{46}$ Ibid para 44

${ }^{47}$ Regulation (EC) No 1049/2001 of the European Parliament and of the Council of 30 May 2001 regarding public access to European Parliament, Council and Commission documents [2001] OJ L-145/43 
the GC. ${ }^{48}$ Similar reasoning was found in the General Court's judgment in CDC Hydrogene Peroxide, where that Court held that the Commission had not satisfied the Regulation's exception, and therefore annulled the Commission's Decision. ${ }^{49}$ These latter decisions, while relevant to the interpretation of the legal rules which govern access to information which may be relevant to the prosecution of claims for cartel damages, do not directly address the balancing of the public and private interests at stake in such applications.

\section{c. Donau Chemie: Absolute Bar to Disclosure}

At issue in Donau Chemie was the consistency of Paragraph 39(2) of the Austrian Law against Cartels (Kartellgesetz 2005) with European law. Paragraph 39(2) provided a blanket prohibition on access to the Cartel Court's files, unless all parties to the proceedings consented. ${ }^{50}$ In the case before the ECJ, the Austrian Cartel Court (Oberlandsgericht Wien, sitting as the Cartel Court) found there to be a cartel in the printing chemical sector. The Cartel Court's decision was subsequently confirmed by the Supreme Court. The industrywide investigation was prompted by a leniency application. ${ }^{51}$

The industry representative of the cartel's customers, the Printing and Media Technology Association, sought access to the court's file "to establish the nature and importance of the prejudice suffered, or to calculate this on the basis of the information contained in the file." ${ }^{52}$ All parties to the proceedings refused their consent, although the Competition Authority would have permitted access to the order of the Cartel Court's ruling. ${ }^{53}$ The trade association made an application for access to the file to the Oberlandsgericht Wien for access to the file, which in turn referred the matter to the ECJ for a preliminary ruling.

The ECJ recognised that a blanket requirement for all parties to consent to disclosure will have the practical effect of systematically denying disclosure to parties who may have an interest in access and no other means to acquire this information. The Court remarked:

\footnotetext{
${ }^{48} E n B W(\mathrm{n} 3)$ paras $171-76$

${ }^{49}$ CDC Hydrogene Perodixe (n 2) para 79

${ }^{50}$ Article 39(2) is quoted in paragraph 3 of the judgment in Donau Chemie (n 4), and reads (in the Court's translation): "Persons, who are not parties to the procedure, may gain access to the files of the Cartel Court only with the consent of the parties."

${ }^{51}$ See Donau Chemie Opinion of the AG ibid paras $14-15$

${ }^{52}$ Ibid para 16

${ }^{53}$ Ibid para 17
} 
In practice this allows for systematic objections to any request for access, inter alia when the requests pertains to documents the disclosure of which is contrary to the interests of the parties to the proceedings, including documents which may contain evidence on which a claim for compensation could be based and which the requesting party cannot obtain by other means. ${ }^{54}$

While the ECJ noted that in the absence of EU rules on point, it is up to member states to develop their legal provisions but in so doing they must ensure the protection and vindication of legal rights granted under European law.

The Court recognised that a rule (such as the Austrian rule) which precluded any access to the file would make the vindication of a claimant's right of private damages difficult, if not impossible. ${ }^{55}$ Likewise, a rule of routine, general disclosure of the file is also inappropriate as such a rule may lead to infringements of other European legal rights of the parties (e. g. privacy, protection of business secrets) and thus possibly the willingness of cartel members to take advantage of leniency programmes. ${ }^{56}$ Accordingly, disclosure must be "conducted by the national courts and tribunals only on a case-by-case basis, according to national law, and taking into account all the relevant factors in the case... ."57

In applying these principles to disclosure of materials contained in leniency files, the ECJ's reasoning emphasises the need to balance considerations of the public interest in having effective leniency programmes against individuals' rights to effectively pursue actions for damages. While leaving the case-by-case balancing in the hands of the national courts, the ECJ made the following observation:

In particular, as regards the public interest of having effective leniency programmes ... the argument that there is a risk that access to evidence contained in a file in competition proceedings which is necessary as a basis for those actions may undermine the effectiveness of a leniency programme in which those documents were disclosed to the competent competition authority cannot justify a refusal to grant access to that evidence.

\footnotetext{
${ }^{54}$ Donau Chemie (n 4) Judgement para 38

${ }^{55}$ Ibid para 32

${ }^{56}$ Ibid para 33

${ }^{57}$ Ibid para 34
} 
By contrast, the fact that such a refusal is liable to prevent those actions from being brought, by giving the undertakings concerned, who may have already benefited from immunity, at the very least partial, from pecuniary penalties, an opportunity also to circumvent their obligation to compensate for the harm resulting from the infringement of Article 101 TFEU, to the detriment of the injured parties, requires that refusal to be based on overriding reasons relating to the protection of the interest relied on and applicable to each document to which access is refused.

The mere risk that a given document may actually undermine the public interest relating to the effectiveness of the national leniency programme is liable to justify the non-disclosure of that document. ${ }^{58}$ [emphasis supplied]

While a case-by-case and document-by-document approach is necessary to ensure all parties' legal rights are respected, documents which risk undermining the efficacy of a leniency programme may be withheld from prospective claimants. It will be interesting to see how widely or narrowly this last point will be construed in the future.

The principles elicited in Pfliederer and its progeny and the subsequent application of these principles by the German and English courts have made a mess out of the EU's leniency programme. The main difficulty is that the ECJ avoided the problem by, in effect, kicking the ball to the Member States and their national courts. The consequences of this are to balkanise the standards by which leniency applications are kept confidential, and do so with retrospective effect. While the Amtsgericht's and the High Court's decisions add a little clarity to German and English law, the ECJ's requirement that disclosure obligations are to be evaluated on a case-by-case basis makes muddies the waters somewhat. Further, though these two member states have clarified disclosure criteria, there are over two dozen more jurisdictions which need to make a similar determination. The consequence of this difficulty can be expressed in one word: uncertainty.

After Pfleiderer, a prospective leniency applicant cannot know which (if any) documents contained in an application will remain out of the hands of prospective Plaintiffs. As such the prospective applicant is unable to accurately assess its exposure, and thus determine the benefits of applying for leniency. This will be a concern for a prospective leniency applicant, as the rough precision demanded for accurate "playing" of the Prisoner's Dilemma games which are leniency programmes is simply no longer present.

${ }^{58}$ Ibid paras $46-48$ 


\section{Harmonising Leniency and Private Enforcement}

At this juncture, we make some observations regarding the prospective leniency applicant's concern. The immediate fear of a leniency applicant is that the applicant will somehow be required to "pay more" as a result of its application (and the possible release of the information contained in the application). There are numerous ways this can occur, some or all of which may be relevant in any given case. These include:

- If their previous participation was unknown (an unlikely, but possible circumstance), this information would become public, thereby exposing them to damages,

- By providing information to public authorities, this information could be used as evidence in subsequent actions, making the case for damages against them easier for Plaintiff's counsel to prove, hence

○ Proof of the extent of their involvement (and thus damages) is facilitated,

○ The applicant may be estopped in denying the truth of the content of the leniency materials they provide, thus making the Plaintiff's case cheaper to prosecute, hence exposing them to damages that may have otherwise been on the other side of a cost-benefit margin.

There are, of course, other possible circumstances where the existence of this information aggravates liability. Nevertheless, the very possession of this information in the hands of the public authorities leads to an increase in the probability of a leniency applicant having to pay a greater amount of damages.

However, these concerns of "paying more" are only relevant when any of the following is/are the case:

a) The (private) damages regimes are sufficiently weak (in the absence of the leniency file) that the presence of the information contained in the file will guarantee a greater recovery, 
b) Drawing on the work of Coase and Williamson ${ }^{59}$ on transaction costs, it may be that as a result of the balkanised nature of the different Member States' private damages regimes is such that the transaction costs (e.g. lawyers' fees) of resolving the claims is significant; or,

c) Private damages regimes may be such as to set up a system of joint and several liability among joint tortfeasors so that exposure to damages may be greater than the harm caused (or, possibly equivalently put, gain received).

d) And these concerns are exacerbated if, as part of the leniency application, additional documents are created which detail the applicant's role in (and potentially, gain from) its cartel activity.

In addressing these concerns we must re-remind ourselves that although private enforcement complements public enforcement, and in spite of protestations to the contrary, ${ }^{60}$ enhancements to one regime may likely have an effect on the other regime. Accordingly, when enhancements need to be made, we must keep the relative hierarchy between public and private enforcement in mind.

To this end, we must consider two distinct questions: first, what is this hierarchy; and, second, what should the hierarchy be. Regarding the first question, Advocate General Mazák, in the author's view, correctly remarks:

I consider that Regulation No 1/2003 and the case-law of the Court have not established any de jure hierarchy or order of priority between public enforcement of EU competition law and private actions for damages. While no de jure hierarchy has been established, at present the role of the Commission and national competition authorities is, in my view, of far greater importance than private actions for damages in ensuring compliance with Articles 101 and 102 TFEU. Indeed so reduced is the current role of private actions for

\footnotetext{
${ }^{59}$ E.g. Ronald Coase, "The Nature of the Firm" (1937) 4 Economica (n. s.) 386 and "The Problem of Social Cost" (1960) 3 Journal of Law and Economics 1, Oliver E. Williamson, "The Economics of Organisation: The Transaction Costs Approach" (1981) 87 American Journal of Sociology 548

${ }^{60}$ See e.g. Alexander Italianer (Director General Directorate General for Competition European Commission) "Public and Private Enforcement of Competition Law" Fifth International Competition Conference (17 February 2012) Brussels available at < http://ec.europa.eu/competition/speeches/text/sp2012_02_en.pdf > accessed 30 August 2013.
} 
damages in that regard that I would hesitate in overly using the term 'private enforcement. $^{, 61}$

At the EU level, while Member States must permit the opportunity for an individual harmed by breaches of Article 101 of the TFEU the opportunity to effectively obtain compensation, the emphasis of anti-cartel enforcement is public. The Commission ferrets out the activity and fines the participants.

In the author's mind, this is as it should be. The emphasis in antitrust enforcement should be focused on effective public enforcement, based on the recognition that public enforcement has a deterrent effect, seeking to prevent the occurrence of conduct before it has a chance to do harm. This is in contrast to the reactive nature of private enforcement, which seeks to redress harm after it has occurred. The deterrent effect which public enforcement has complements the recognition of the nature of markets as being a fundamental principle of distributive justice in a liberal society. ${ }^{62}$ This latter point, as I have argued elsewhere, justifies the use of the criminal law to prevent this sort of market abuse, thus underscoring the legitimacy of the primacy of the public enforcement regime. ${ }^{63}$

Hence, if cartel activity is harmful, which it is almost unanimously believed to be, then the goal of an anti-cartel regime should be to prevent, by deterring this harm. In every respect this approach should mirror any regulation of activity which (if left un- or underregulated) could lead to harm: $:{ }^{64}$ it is preferable to prevent people from becoming victims than to allow them to become victims and provide a means to allow for their compensation afterwards. Accordingly, there are strong reasons to prefer public enforcement to trump private enforcement, in the event of a conflict.

\section{a. Disclosure}

${ }^{61}$ Pfleiderer (n 1) Opinion of the Advocate General para 40

${ }^{62}$ See e.g. Bruce Wardhaugh "A Normative Approach to the Criminalisation of Cartel Activity" (2012) 32 Legal Studies 369, and Angus MacCulloch, "The Cartel Offence: Defining an Appropriate 'Moral Space'” (2012) 8 European Competition Journal 73. ${ }^{63}$ See Wardhaugh ibid

${ }^{64}$ Of course, it is another issue to determine what sorts of harms need regulating. This question is well beyond our present topic (but see Wardhaugh ibid). All which need be said at this juncture is that ex hypothesi anti-competitive harm through cartel activity is one such harm. 
Addressing the above concerns in reverse order, I make the following suggestions. First, the greatest weakness of ECJ's judgment in Pfleider is that judgment's treatment of the disclosure of documents created expressly for the purposes of the leniency applications. But for the application, these documents simply would not have existed. The Advocate-General correctly noted not only this point; but also noted that in creating such statements a leniency applicant would have a legitimate expectation of confidentiality (at least with regard to potential damage claimants) regarding their contents. Were such documents subject to disclosure, a leniency programme is less advantageous. ${ }^{65}$

Although in NGET Mr Justice Roth held that a leniency applicant had no legitimate expectation regarding the confidentiality of its application, I must disagree with this assertion. The documents created for the purpose of such an application are highly self-incriminatory; particularly given the need for the applicant's cooperation (and creation of further documents) to - in effect—-decode other documents which describe the cartel's structure and operations. It is simply unlikely that such (potential) evidence would be created without an expectation of confidentiality — or at minimum, that it would not somehow enhance the applicant's exposure to damages.

Article 6 of the Proposed Directive would prohibit the disclosure at any time of corporate leniency statements and settlement submissions, ${ }^{66}$ and would permit national courts to disclose:

... the following categories of evidence only after a competition authority has closed its proceedings or taken a decision referred to in Article 5 of Regulation No 1/2003 or in Chapter III of Regulation No 1/2003:

(a) information that was prepared by a natural or legal person specifically for the proceedings of a competition authority;

(b) information that was drawn up by a competition authority in the course of its proceedings. $^{67}$

Information which does not fit into the above exceptions may be disclosed at any time. ${ }^{68}$

\footnotetext{
${ }^{65}$ See the Opinion of the AG in Pfleiderer, quoted in text accompanying $\mathrm{n} 30$.

${ }^{66}$ Proposed Directive (n 7) Article 6(1)

${ }^{67}$ Ibid Article 6(2)

${ }^{68}$ Ibid Article 6(3)
} 
I suggest that this proposed Article goes a significant way to ameliorating the concerns of confidentiality for statements which were created expressly for the purposes of a leniency application. Additionally, settlement discussions are typically conducted on an assumption of (or possibly an express recognition of) a "without prejudice basis." To entrench this level of confidentiality into a Europe-wide legal principle underscores those expectations possessed by the parties in such negotiations with competition authorities.

b. Joint and Several Liability

One solution to joint and several liability concerns can be addressed by decoupling them for successful leniency applicants. This was the American solution in ACPERA. Given the decentralised nature of private competition law enforcement, this (or any other harmonisation of a civil damages regime) requires coordinated action among all member states. An alternative and intriguing solution is to embark along the lines of Article 88/D of the Hungarian Competition Act ${ }^{69}$ which provides:

Any person to which immunity from fine was granted under Article 78/A may refuse to pay damages for the harm caused by his conduct infringing Article 11 of this Act or Article 81 of the EC Treaty until the claim can be recovered from any other person responsible for causing harm by the same infringement. This rule is without prejudice to the possibility of bringing a joint action against persons causing the harm. Lawsuits initiated to enforce claims against persons responsible for harm-causing to which immunity from fine was granted shall be stayed until the date on which the judgement made in the administrative lawsuit initiated upon request for a review of the decision of the Hungarian Competition Authority establishing an infringement becomes legally binding.

Joint and several liability remains, however, the successful leniency applicant becomes the last target for recovery.

The Proposed Directive leans toward the American approach. Article 11(1) of the Proposed Directive would require member states to ensure that their private damages regime provides for joint and several liability for competition law infringements. Articles 11(2) and

${ }^{69}$ Act LVII of 1996 (as amended) 
(3) limit the civil exposure of an immunity recipient. The former paragraph excludes the immunity recipient's for liability for damages to parties other than its own (direct or indirect) purchasers except where such purchasers cannot obtain compensation from other undertakings. The latter paragraph caps an immunity recipient's liability to "the amount of the harm it caused to its own direct or indirect purchasers or providers." 70

Again, this is a step forward. There are at least three advantages of such a regime. First, those harmed will be compensated, even if some cartel members have become insolvent or are otherwise judgment-proof. Second, the value of being a successful leniency applicant is enhanced. Such an applicant is in effect rewarded by having damages for what it would otherwise be liable paid by another undertaking. Such a regime enhances the reward in the Prisoner's Dilemma that a leniency applicant finds itself.

Finally, knowledge of the amount of harm caused by a particular Defendant is within the knowledge of that Defendant, as they have the necessary information which will permit the calculation of this harm. They are thus best placed to make this calculation. A Defendant (who is a successful leniency applicant) thus need not calculate the harm caused by other cartel participants (and not having the appropriate information, they may not be well placed to make such a calculation). Additionally such a successful leniency applicant need not investigate the solvency (or take the risk of insolvency) of other cartel members. Accordingly, the calculations demanded by the Prisoners' Dilemma element of a leniency programme are greatly facilitated.

c. Multiplicity of Jurisdictions and Private Actions

The second point, the transaction costs of applying for leniency and potentially defending oneself in numerous member states is an unfortunate consequence of the parallel competencies of the member states and the Commission. While an attempt to develop a model leniency programme through the European Competition Network is laudable, unless such a programme is universally implemented and appropriately coordinated, such transaction costs will continue to exist. Indeed, at present, as the court noted in Pfleiderer, the model programme "has no binding effect on the courts and tribunals of the Member States."71 There is thus a strong case to be made that the efficacy of leniency programmes as an element

\footnotetext{
${ }^{70}$ Proposed Directive (n 7) Art 11(3)

${ }^{71}$ Pfliederer (n1) Judgement para 22
} 
of effective public enforcement cries out for a better coordinated, one-stop shop, PanEuropean leniency programme.

The multiplicity of jurisdictions in which damage claims can be brought is a fact of EU life. However, if the cartel is only of local significance (e.g. a regional or national one) then this is of little concern. In seeking damages against members of a "small" European cartel (e.g. affecting only a few member states) the transaction costs increase. With larger, more geographically spread cartels, these sorts of transaction costs may be significant. Absent a European-wide tribunal to resolve, inexpensively, numerous claims arising out of the effects in several Member States of the same activity, ${ }^{72}$ such costs may be significant. Yet, from the point of view of preventing cartel activities, the existence of such costs may act as an addition deterrent.

Although a European-wide tribunal to resolve the claims which may arise from a cartel operating in a number of jurisdictions may be a step too far at this point in time, the Proposed Directive goes part way to reducing the transaction costs associated with pursuing claims in a number of jurisdictions. Article 9 of the Proposed Directive would require Member States to ensure that their courts do not take decisions contrary to final infringement decisions of a "national competition authority or by a review court."73 This parallels the provisions of Article 16 of Regulation 1/2003 ${ }^{74}$ which prohibit national courts from taking decisions contrary to the findings of the Commission. The effect of the is Article of the Proposed Directive is to make these decisions of national authorities res judicata throughout Europe, thereby ensuring that such findings need not be re-litigated, thus economising on the costs of litigation.

d. Strengthening Private Actions

The first point, that existing private damage regimes are sufficiently weak, so that the disclosure of the contents of a leniency application merely enhances recovery for aggrieved parties, would be nothing more than an indictment of a particular Member State's civil

${ }^{72}$ See Jacob Rüggerberg and Maarten Pieter Schinkel, "Consolidating Antitrust Damages in Europe: A Proposal for Standing in line with Efficient Private Enforcement" Amsterdam Center for Law and Economics Working Paper No. 2006-04 (SSRN 903282) for an interesting proposal along this line.

${ }^{73}$ Proposed Directive (n 7) Art 9

${ }^{74}$ Council Regulation (EC) No 1/2003 of 16 December 2002 on the implementation of the rules on competition laid down in Articles 81 and 82 of the Treaty [2003] O J L-1/1 
regime for the enforcement of Article 101 of the TFEU. In the absence of a damage "multiplier" (e.g. of the sort found in American law) a "greater" recovery can never exceed the plaintiff's loss. Were the relevant Member State's liability regime unable to permit the Plaintiff to recover its loss, such regime would be a breach of that Member State's obligations under, inter alia, Crehan and Manfredi. There is, however, a legitimate concern that this is the case. There is a growing body of empirical evidence, led by Connor, ${ }^{75}$ which suggests that the European private enforcement regime is inadequate in obtaining effective redress for those harmed by such anti-competitive behaviour. If so, this is an argument to either strengthen the private regime, or to engineer the public regime to increase its deterrent effect there by reducing the need for post facto compensation.

This review of the interaction between leniency and private enforcement suggests two conclusions. First, the current private regime is far too weak. Indeed, if there is a legitimate fear that by applying for leniency, one's exposure to damages will increase, this suggests that the present system undercompensates victims. Second, the costs of applying (or not applying, as may be the case) for leniency are all internalised to the undertaking involved. This removes the private interests of the firm's agents from the equation. By so doing, the present leniency scheme is unable to create and exploit any potential conflict between the agent's own interest and that of the undertaking to enhance the destabilisation of cartels and bring about their prosecution.

One means of strengthening the private regime would have been through the development of collective redress (so-called "class actions"). Such a regime can facilitate recovery of a large number of small amounts, which individually would be uneconomical to attempt to recover. The Proposed Directive is silent about collective redress. However, on the same day as the Proposed Directive was published, the European Commission recommended to Member States that they consider putting into place systems for collective redress for competition damages. ${ }^{76}$ Although in Europe, the idea of collective redress for competition matters has been a topic of discussion for a number of years, ${ }^{77}$ as the

\footnotetext{
75 John Connor, "Global Antitrust Prosecutions of Modern International Cartels" (2004) 4 Journal of Industry, Competition, and Trade 239, for a review of some of this work see e.g. Bruce Wardhaugh "Closing the Deterrence Gap" (2011) 10 Competition Law Journal 175. ${ }^{76}$ European Commission, Press Release, "Commission recommends Member States to have collective redress mechanisms in place to ensure effective access to justice" (11 June 2013) IP/13/524

${ }^{77}$ See Ashurst (A Firm), Study on the conditions of claims for damages in case of infringement of EC competition rules (EC Commission, Competition DG, 31 August 2004),
} 
Commission notes that Member States have different traditions regarding collective redress, which need to be respected. ${ }^{78}$ Mandatory collective redress is likely another step too far.

The American experience shows that personal sanctions could be used to further enhance the instability found in cartel arrangements. As addressed in the introductory part of this paper, we outlined the agency issues associated with corporate activity. Illegal "corporate" activity has its origins in the agency relationship, and the divergent interests of the agent and the firm can be exploited to undermine any trust which may be latent in the cartel arrangement. When faced with individual sanctions, the agent is likely to consider their own interest first (if not exclusively), and is therefore more likely to be cooperative with authorities in their investigation of collusion.

Although the addition of criminal sanctions may enhance leniency programmes, at this point incorporating criminal sanctions to EU law is unrealistic. Such addition would require an expenditure of a significant amount of political will on advancing what may be seen as an Anglo-Saxon goal in the competition agenda, ${ }^{79}$ and is unlikely to have widespread popular support. ${ }^{80}$ At this point in time, it would be another step too far to suggest Europeanwide criminalisation of such activity.

Green Paper Damages actions for breach of the EC antitrust rules Brussels, 19.12.2005 $\operatorname{COM}(2005) 672$ final, Making antitrust damages actions more effective in the EU: Welfare impact and potential scenarios (Report For The European Commission Contract DG COMP/2006/A3/012, 21 December 2007), White Paper on Damages actions for breach of the EC antitrust rules (n 29), and Commission Staff Working Paper accompanying the White Paper on Damages actions for breach of the EC antitrust rules $\{\mathrm{COM}(2008) 165$ final $\}\{$ SEC (2008) 405\} \{SEC (2008) 406\} Brussels, 2.4.2008 SEC(2008) 404, Arianna Andreangeli, "Collective Redress in EU Competition Law: An Open Question with Many Possible Solutions" (2012) 35 World Competition 529, and Roger Van den Bergh, "Private Enforcement of European Competition Law and the Persisting Collective Action Problem" (2013) 20 Maastricht Journal of European and Comparative Law 12.

${ }^{78}$ See Press Release $n 76$

${ }^{79}$ See Former President Sarkozy's remarks on the Lisbon Treaty: "Nous avons obtenu une réorientation majeure des objectifs de L'Union. La concurrence n'est plus un objectif de l'Union ou un fin en soi, mais un moyen au service du marché intérieur." ("We have obtained a major reorientation of an objective of the Union. Competition is no longer an end in itself, but a means I service of the internal market." Present author's translation) Quoted in Ben Van Rompuy, "The Impact of the Lisbon Treaty on EU Competition Law: A Review of Recent Case Law of the EU Courts" CPI Antitrust Chronicle December 2011 (1) at 2. (Electronic copy available at: http://ssrn.com/abstract=1970081, accessed 30 August 2013). ${ }^{80}$ See e.g. Vasiliki Brisimi and Maria Ioannidou, "Criminalizing Cartels in Greece: A Tale of Hasty Developments and Shaky Grounds" (2011) 34 World Competition 157 and Andreas 
However, notwithstanding the impracticalities of criminalisation, I suggest that any resolution to the difficulties raised by Pfleiderer be resolved in favour of public enforcement: a public regime acts as an ex ante deterrent, by preventing the activity in the first place. If cartel activity does inflict harm, prevention of harm - as opposed to compensating the harmed - appears to be the socially preferable strategy, and is a strategy which can be implemented on a case-by-case, document-by-document basis.

\section{Conclusion}

The ECJ's judgement in Pfleiderer and the proposed Directive which was published in response to it could - in several senses - be regarded as two steps forward and one step back in European cartel enforcement. The most significant advance made was the recognition of the importance of access to documents in civil actions. But the importance here is very double edged. While they are useful, indeed essential, to prospective Plaintiffs in their attempts to seek redress for the harms done to them, to Defendants their existence will aggravate their liability. And self-incriminating leniency applications will be the most useful (for Plaintiffs) and the most harmful (for Defendants) of this sort of documents. In the absence of European legislation on point, the ECJ had little choice to do what it did: in effect kicking the ball back to the Member States, leaving the situation-for both Plaintiffs and Defendants - unclear and unsatisfactory.

In this regard, the proposed Directive makes significant steps forward. It recognises the need to keep such disclosure applications confidential, to facilitate their production for the purposes of competition enforcement. In effect, the proposed Directive establishes a hierarchy which places public enforcement concerns over private enforcement concerns. This, we argued, is as it should be: all other things being equal, harm prevention should be prioritised over compensation for harms. The proposed rules regarding confidentiality of such documents ensures that the balance is (or continues to be) tipped in favour of public enforcement.

But the proposed Directive's greatest failing is that it did not go far enough. The proposed Directive should have addressed the position of a prospective leniency applicant to

Stephan, "Survey of Public Attitudes Towards Price-Fixing and Cartel Enforcement in Britain" (2008) 5 Competition Law Review 123. There are additional normative considerations involved in a pan-European cartel criminalisation project: see Wardhaugh, "A Normative Approach" (n 62) 395. 
ensure that the applicant is made "no worse off" in any subsequent civil action by the application. While there is an argument that rewarding applicants and whistle-blowers by providing with some advantage vis-à-vis their co-conspirators further enhances cartel instability ${ }^{81}$ this may go too far. Rewarding a "guilty party" may appear distasteful in some European legal cultures, some of which may frown on plea-bargains, settlements, and bounties. However, mandating that the applicant is no worse off as a result of the application should have been a priority for those drafting the proposed Directive. Such a statement would have enhanced the efficacy of leniency programmes and public enforcement by giving prospective applicants the assurance they need.

Expanding on this point, while leniency documents and their production may be one instance of a conflict between the public and private enforcement regimes, it need not be the only such conflict. A more forceful and more general rule for the resolution of such conflicts in favour of public enforcement would prevent repetition of the scenario which developed in Pfleiderer. That is, a conflict between the public and private regime develops, the absence of EU law on point requires the ECJ to mandate the resolution to the conflict by national law, but given the multiplicity of national laws, no clear or predictable result is apparent to the Court. EU legislation is needed, and a somewhat narrow piece of legislation is developed some years later. This proposed Directive, had it been a more sweeping response could possibly have eliminated such a future need. If so, this was an opportunity lost.

$\overline{{ }^{81} \text { See Aubert, Rey and Kovacic (n 16) }}$ 